AKRUAL 5 (1) (2013): 59-74 $e$-ISSN: 2502-6380

\title{
AKRUAL
}

Jurnal Akuntansi

http://fe.unesa.ac.id/ojs/index.php/akrl

\section{ANALISIS PENGARUH SIKAP, NORMA SUBYEKTIF, DAN KONTROL KEPERILAKUAN TERHADAP PERILAKU KEPATUHAN WAJIB PAJAK RESTORAN DI SURABAYA}

\author{
Femka Dyan \\ Lintang Venusita \\ Jurusan Akuntansi Fakultas Ekonomi Universitas Negeri Surabaya \\ Email: lvenusita@gmail.com \\ Artikel diterima: 10 Agustus 2013 \\ Terakhir direvisi: 5 September 2013
}

\begin{abstract}
Tax arrears increased area in Surabaya. One of the biggest delinquent taxes derived from the Restaurant. It is proved that the level of tax compliance is lacking Restaurant. This study examines the behavior of tax compliance by using variable bebas Attiude, Subjective Norms, and Behavioral control. The purpose of this study is to determine how much influence attitudes, subjective norms, and behavioral control toward tax compliance behavior Restaurant taxpayer in Surabaya. The population in this study are all Restaurants taxpayer in Surabaya. The sample used was 94 Taxpayer Restaurant. The data analysis technique used in this study multiple linear regression. Based on the results of the analysis carried out it could be concluded that attitudes, subjective norms and behavioral control significantly positive effect on tax compliance behavior Restaurant.
\end{abstract}

Keyword: Attitude, Subjective Norm, and Behavior Control, and Compliance Behavior of tax payers

\section{PENDAHULUAN}

Dalam upaya mendukung pelaksanaan pembangunan nasional, pemerintah memberikan kesempatan untuk menyelenggarakan otonomi daerah dengan mengeluarkan Undang-Undang No. 12 Tahun 2008 Perubahan Kedua atas UndangUndang No. 32 Tahun 2004 tentang Pemerintahan Daerah dan Undang-Undang Nomor 33 Tahun 2004 tentang Perimbangan Keuangan antara Pemerintah Pusat dan Pemerintah Daerah. Menurut Undang-Undang Nomor 12 Tahun 2008 tentang Pemerintahan Daerah, otonomi daerah merupakan kewenangan daerah otonom untuk mengatur dan mengurus kepentingan masyarakat setempat menurut prakarsa sendiri berdasarkan aspirasi masyarakat sesuai dengan peraturan perundang-undangan. Kewenangan daerah mencakup kewenangan pemerintahan, mulai dari sistem perencanaan, pembiayaan maupun pelaksanaannya.

Seiring dengan diberlakukannya otonomi daerah, maka dikenal pula istilah desentralisasi fiskal. Desentralisasi fiskal berarti pendelegasian kewenangan dan 
tanggung jawab fiskal dari pemerintah pusat kepada pemerintah daerah. Berlakukannya kebijakan desentralisasi fiskal, maka daerah diberikan kebebasan untuk mengatur sistem pembiayaan dan pembangunan daerahnya sesuai dengan potensi dan kapasitasnya masing-masing.

Undang-Undang Nomor 33 Tahun 2004 tentang Perimbangan Keuangan antara Pemerintah Pusat dan Pemerintah Daerah mengisyaratkan bahwa dalam rangka pelaksanaan otonomi daerah dan desentralisasi fiskal, pemerintah daerah diberi keleluasaan untuk mengelola dan memanfaatkan sumber penerimaan daerah yang dimilikinya sesuai dengan aspirasi masyarakat daerah. Untuk melaksanakan dan menyelenggarakan otonomi daerah secara luas, nyata, dan bertanggung jawab

diperlukan kewenangan dan kemampuan daerah untuk menggali sumber-sumber keuangan sendiri yang didukung oleh perimbangan keuangan antara pemerintah pusat dan pemerintah daerah. Dengan demikian, pemerintah daerah harus mampu menggali sumber-sumber keuangan sendiri agar dapat melaksanakan fungsinya secara efektif dan efisien, yakni dalam bidang pemerintahan dan pelayanan umum kepada masyarakat.

Dengan demikian tugas dan tanggung jawab Pemerintah Daerah Kabupaten dan Kota untuk mewujudkan Otonomi Daerah dalam mengurus rumah tangganya sendiri semakin berat. Oleh karena itu, pemerintah daerah harus mengoptimalkan sumber-sumber penerimaan daerah Berdasarkan Undang-Undang Nomor 33 Tahun 2004 tentang Perimbangan Keuangan antara Pemerintah Pusat dan Pemerintah Daerah.

Salah satu sumber penerimaan daerah terbesar berasal dari Pendapatan Asli Daerah (PAD). Pendapatan Asli Daerah (PAD) merupakan salah satu indikator yang menentukan derajat kemandirian suatu daerah. Semakin besar penerimaan PAD suatu daerah maka semakin rendah tingkat ketergantungan pemerintah daerah tersebut terhadap pemerintah pusat. Sebaliknya, semakin rendah penerimaan PAD suatu daerah maka semakin tinggi tingkat ketergantungan pemerintah daerah tersebut terhadap pemerintah pusat. Hal ini dikarenakan PAD merupakan sumber penerimaan daerah yang berasal dari dalam daerah itu sendiri. Sumber Pendapatan Asli Daerah yang memiliki peranan penting berasal dari Pajak Daerah. Pajak Daerah memiliki potensi yang sangat tinggi dalam menambah jumlah anggaran Pendapatan Asli Daerah. Adapun jenis Pajak daerah menurut Peraturan Daerah No 4 Tahun 2011 di Surabaya yaitu Pajak Hotel, Pajak restoran, pajak hiburan, pajak reklame, pajak penerangan jalan, pajak parkir, pajak air tanah, pajak burung sarang walet. Diantara pajak-pajak tersebut Pajak restoran merupakan salah satu pajak yang memiliki andil besar terhadap penerimaan Pajak Daerah.

Pajak Restoran merupakan pajak atas pelayanan yang disediakan oleh restoran. Mulai tahun 2011 setelah dikeluarkannya Perda Nomor 4 tahun 2011 di Surabaya sistem pemungutan Pajak Restoran tidak lagi menganut Official Assesment tetapi berubah menjadi Self Assesment. Sistem ini diberlakukan untuk memberikan kepercayaan bagi masyarakat guna meningkatkan kesadaran dan peran serta masyarakat dalam menyetorkan pajaknya. Konsekuensi dari sistem ini adalah bahwa 
masyarakat/Wajib Pajak harus benar-benar mengetahui tata cara perhitungan pajak dan segala sesuatu yang berhubungan dengan pelunasan pajaknya, seperti kapan harus membayar pajak, bagaimana menghitung besar pajak, perhitungan, atau sanksi apa yang akan diterima bila melanggar ketetapan pajak. Self assessment ini diharapkan dapat meningkatkan kepatuhan wajib pajak, yang ditandai dengan pelaksanaan kewajiban perpajakannya oleh wajib pajak secara sukarela dan sesuai dengan ketentuan Undang-Undang dan Peraturan Perpajakan yang berlaku. Oleh karena itu, peran serta masyarakat menjadi sangat penting dan sebagai penentu didalam menopang pembiayaan pembangunan melalui pajak.

Masalah yang diberitakan menurut Antara news mengatakan bahwa tunggakan pajak daerah di Surabaya pada tahun 2011 mencapai 31,7 milyar. Tunggakan tersebut berasal dari pajak hotel, restoran, hiburan, reklame, penerangan jalan dan parkir. Sumber terbesar tunggakan berasal dari pajak restoran yang mencapai Rp12,515 miliar, disusul berikutnya pajak reklame Rp8,929 miliar, ketiga diduduki pajak hotel Rp8,117 miliar, pajak hiburan yang memiliki tunggakan Rp1,433 miliar, pajak parkir Rp639,029 juta dan pajak penerangan jalan Rp92,855 juta.

Hal ini diperkuat oleh laporan harian Seputar Indonesia yang mengatakan komisi B DPRD merasa kecewa atas kinerja Dinas Pengelolaan dan Penerimaan Keuangan (DPPK) pemkot Surabaya memasuki triwulan II tunggakan Pajak Restoran di Surabaya mencapai 4 milyar. Tindakan wajib pajak tersebut jelas melanggar sebab pajak yang akan disetorkan itu bukan dari uang pribadi atau uang perusahaan, melainkan uang negara yang telah dipungut dari masyarakat sesuai dengan ketentuan yang telah ditetapkan. Data yang diperoleh penulis dari DPPK hingga akhir tahun 2012 tunggakan semakin meningkat Pajak Restoran mencapai 15 milyar.

Penelitian mengenai kepatuhan pajak sudah sering dilakukan. Beberapa peneliti menggunakan kerangka model Theory of Planned Behavior (TPB) untuk menjelaskan perilaku kepatuhan Wajib Pajak Orang Pribadi. Model Theory of Planned Behaviour (TPB) yang digunakan dalam penelitian memberikan penjelasan yang signifikan, bahwa perilaku tidak patuh (noncompliance) Wajib Pajak sangat dipengaruhi oleh variabel sikap, norma subyektif, dan kontrol keperilakuan yang dipersepsikan (Mustikasari, 2007:3). Theory of Planned Behavior itu merupakan pengembangan dari Theory of Reasoned Action dengan memasukkan variabel baru yang dapat mempengaruhi niat atau mempengaruhi perilaku, yaitu kontrol keprilakuan yang dirasakan. Teori ini mengenali adanya kemungkinan bahwa banyak perilaku tidak berada dalam kontrol keprilakuan yang dirasakan dan secara penuh. Akan tetapi, jika kontrol keprilakuan yang dirasakan mendekati maksimumnya, yaitu ketika persoalan-persoalan tentang kontrol tidak dalam pertimbangan penting seseorang, maka Theory of Planned Behavior berkurang menjadi Theory of Reasoned Action. Dalam kondisi seperti ini, niat ataupun perilaku tidak akan dipengaruhi oleh keyakinan tentang kontrol keprilakuan. Variabel yang berpengaruh tinggal sikap terhadap perilaku dan norma subyektif. 
Masalah tersebut membuktikan bahwa tingkat kepatuhan dan kesadaran Wajib Pajak Restoran untuk memenuhi kewajibannya dirasa kurang, sehingga Wajib Pajak merasa membayar pajak berarti mengurangi nilai pendapatannya. Akhirnya penyalahgunaan jumlah pajak mereka lakukan. Hal ini sesuai dengan penelitian Linda (1997) menyimpulkan bahwa pelaksanaan self assessment belum bisa diterapkan oleh Wajib Pajak Orang Pribadi terutama pemilik kost dan rumah makan, karena mereka sering kali tidak melaporkan atau mencantumkan Pajak Penghasilannya di SPT. Perlu ditumbuhkan kesadaran dan kepatuhan Wajib Pajak untuk memenuhi kewajiban pajak sesuai dengan ketentuan yang berlaku untuk mencapai target pajak.

Peran dan partisipasi seluruh masyarakat tanpa memandang dari golongan manapun sangatlah dibutuhkan demi kelancaran reformasi perpajakan. Titik berat dalam keberhasilan reformasi perpajakan ini adalah menumbuhkan tingkat kesadaran masyarakat sebagai Wajib Pajak untuk melakukan perwujudan dari pengabdian dan peran serta Wajib Pajak untuk secara langsung dan bersama-sama melaksanakan kewajiban perpajakannya, bertanggung jawab atas kewajiban pelaksanaan pajak sebagai pencerminan kewajiban serta melaksanakan kegotongroyongan nasional melalui sistem menghitung, memperhitungkan, membayar, dan melaporkan sendiri pajak yang terutang (Admino:2009).

Berdasarkan latar belakang di atas maka penulis berketetapan untuk meneliti dan mengkaji sejauh mana sikap, norma subyektif dan kontrol keperilakuan mempengaruhi perilaku kepatuhan Wajib Pajak Restoran di Surabaya.

\section{KAJIAN PUSTAKA}

\section{Kepatuhan Wajib Pajak}

Menurut Musgrave (1993:274) merupakan pelaksanaan atas kewajiban untuk menyetor dan melaporkan pajak yang terutang sesuai dengan ketentuan perpajakan. Kepatuhan yang diharapkan adalah kepatuhan yang sukarela (voluntary compliance) bukan kepatuhan yang dipaksakan (compulsory compliance). Untuk meningkatkan kepatuhan sukarela dari Wajib Pajak diperlakukan keadilan dan keterbukaan dalam menerapkan peraturan perpajakan, kesederhanaan peraturan dan prosedur perpajakan dan pelayanan yang baik dan cepat terhadap Wajib Pajak.

Kepatuhan pemenuhan kewajiban perpajakan merupakan hal yang sangat penting dalam rangka reformasi perpajakan dan menciptakan sistem perpajakan yang baik.Nurmantu (2003:148) menyatakan bahwa kepatuhan perpajakan dapat didefinisikan sebagai suatu keadaan dimana Wajib Pajak memenuhi semua kewajiban perpajakannya dan melaksanakan hak perpajakannya.

Kepatuhan Wajib Pajak merupakan perwujudan dari sikap disiplin Wajib Pajak terhadap hak dan kewajibannya dalam membayar dan melaporkan jumlah pajak yang terutang sesuai dengan peraturan perpajakan. Kepatuhan pajak dapat dimotivasi dengan adanya kebijaksanaan perpajakan yang bersifat formal mengikat, dalam arti dapat mendorong perilaku kepatuhan Wajib Pajak untuk menjadi patuh, dan harus ada sanksi hukum yang bersifat memaksa (the strong approach) berupa kebijakan perpajakan yang mengandung pelaksanaan bagi yang tidak memenuhi syarat 
kepatuhan. Sanksi hukum tersebut juga harus diberikan kepada setiap Wajib Pajak yang telah memenuhi syarat dan tidak patuh. Karena pada dasarnya setiapkebijaksanaan sebagai produk hukum di bidang perpajakan tidak akan bermakna apabila tidak dilaksanakan secara pasti. (Suandy:2001).

Kepatuhan Wajib Pajak (tax compliance) dapat diidentifikasi dari kepatuhan Wajib Pajak dalam mendaftarkan diri, kepatuhan untuk menyetorkan kembali Surat Pemberitahuan, kepatuhan dalam penghitungan dan pembayaran pajak terutang, dan kepatuhan dalam pembayaran tunggakan. Isu kepatuhan menjadi penting karena ketidakpatuhan secara bersamaan akan menimbulkan upaya penghindaran pajak, seperti tax evasion dan tax avoidance, yang mengakibatkan berkurangnya penyetoran dan pajak ke kas negara maupun daerah. Pada hakekatnya kepatuhan Wajib Pajak dipengaruhi oleh kondisi sistem administrasi perpajakan yang meliputi tax service dan tax enformance . perbaikan administrasi perpajakan sendiri diharapkan dapat mendorong kepatuhan.

Menurut Soekanto (1985:32) sikap patuh seseorang terhadap peraturan didorong oleh empat hal, yaitu:

1. Adanya perhitungan untung rugi, dengan perhitungan patuh pada hukum karena adanya keuntungan

2. Adanya tujuan untuk memelihara hubungan baik dengan sesama atau penguasa

3. Karena hukum itu sendiri sesuai dengan hati nuraninya

4. Karena adanya tekanan-tekanan tertentu.

\section{Pajak Restoran}

Restoran merupakan tempat menyantap makanan dan/atau minuman yang disediakan dengan dipungut bayaran, yang termasuk jasa boga dan katering menurut peraturan pemerintah baru.Menurut Peraturan Daerah Kota Surabaya Nomor 4 Tahun 2011 tentang Pajak Restoran adalah pajak atas pelayanan yang disediakan oleh restoran.

Menurut Siahaan (2006:271) Pajak Restoran adalah pajak atas pelayanan restoran. Menurut Yani (2009:55) pajak restoran adalah pajak atas pelayanan restoran.Sehingga dapat disimpulkan bahwa pajak restoran adalah pajak yang hanya dikenakan atas pelayanan yang disediakan oleh restoran yang termasuk jasa boga dan katering.

\section{Dasar Hukum Pajak Restoran}

Undang-Undang Nomor 28 Tahun 2009 tentang Pajak Daerah dan Retribusi Daerah menyatahkan bahwa Pajak daerah dan Retribusi Daerah salah satu sumber Pendapatan Asli Daerah yang penting guna membiayai penyelenggaraan Pemerintahan Daerah dan Pembangunan Daerah untuk menetapkan Otonomi Daerah yang nyata, dan bertanggung jawab. Selanjutnya dalam pasal 2 ayat (2) UndangUndang tersebut, mengatur tentang jenis-jenis Pajak Daerah dimana Pajak Restoran merupakan salah satu Pajak Kabupaten/Kota. 
Peraturan Pemerintah Nomor 91 Tahun 2010 Tentang jenis pajak daerah yang dipungut berdasarkan penetapan kepala daerah atau dibayar sendiri oleh wajib pajak. Untuk melaksanakan ketentuan Pasal 98 Undang-Undang Nomor 28 Tahun 2009 tentang Pajak Daerah dan Retribusi Daerah, perlu menetapkan Peraturan Pemerintah tentang Jenis Pajak Daerah yang Dipungut Berdasarkan Penetapan Kepala Daerah atau Dibayar Sendiri oleh Wajib Pajak. Selanjutnya dalam pasal 2 ayat 3 menyatakan bahwa pajak Kota/Kabupaten termasuk Pajak Restoran.

Peraturan Daerah Kota Surabaya Nomor 4 Tahun 2011 tentang Pajak Daerah. Di dalam Peraturan Daerah tersebut mengatur tentang jenis-jenis Pajak Daerah yang diberlakukan di kota Surabaya beserta tata cara pembayaran, tata cara perhitungan, dasar pengenaan, tarif yang diberlakukan, kelebihan pembayaran, masa pemungutan, saat terutang pajak, wilayah pemungutan dan lain sebagainya yang berhubungan dengan pajak daerah.

\section{Objek,Subyek dan Wajib Pajak}

Pengertian Objek Pajak Restoran menurut Peraturan Daerah Kota Surabaya Nomor 4 Tahun 2011adalah pelayanan yang disediakan di Restoran meliputi restoran, rumah makan, kafetaria, kantin, warung, depot, puja sera/food court, toko roti/ bakery, jasa boga/katering dan kegiatan usaha lainnya yang sejenis.

Pengertian Subyek Pajak Restoran menurut Peraturan Daerah Kota Surabaya Nomor 4 Tahun 2011adalahorang pribadi atau Badan yang membeli makanan dan/atau minuman dari Restoran, tidak termasuk subyek pajak restoran adalah konsulat, kedutaan dan perwakilan negara asing dengan asas timbal balik.

Pada Pajak Restoran yang menjadi wajib pajak adalah Pengusaha Restoran, yaitu orang pribadi atau badan dalam bentuk apapun yang dalam lingkungan perusahaan atau pekerjaannya melakukan usaha dibidang rumah makan. Dengan demikian, subyek pajak dan wajib pajak pada Pajak Restoran tidak sama. Konsumen yang menikmati pelayanan restoran merupakan subyek pajak yang membayar pajak sedangkan pengusaha restoran bertindak sebagai wajib pajak yang diberi kewenangan untuk memungut pajak dari konsumen (subyek pajak) Siahaan (2006:274).

\section{Dasar Pengenaan dan Tarif Pajak Restoran}

Dasar pengenaan Pajak Restoran Menurut Peraturan Daerah Kota Surabaya Nomor 4 Tahun 2011 adalah jumlah pembayaran yang diterima atau yang seharusnya diterima Restoran. Pembayaran adalah jumlah uang yang harus dibayaroleh subyek pajak kepadawajib pajak untuk harga jual baik jumlah uang yang dibayarkan maupun penggantian yang seharusnya diminta wajib pajak sebagai penukaran atas pembelian makanan dan atau minuman.

Tarif pajak Restoran ditetapkan sebesar 10\% (sepuluh persen) menurut Peraturan Daerah No. 4 Tahun 2011 di Surabaya. Besarnya pokok pajak restoran yang terutang dihitung dengan cara mengalikan tarif pajak dengan dasar pengenaan pajak. 


\section{Hipotesis Penelitian}

$\mathrm{H}_{1}$ : Sikap, norma subyektif dan kontrol keperilakuan berpengaruh secara simultan terhadap kepatuhan Wajib Pajak Restoran di Surabaya.

$\mathrm{H}_{2}$ : Sikap, norma subyektif dan kontrol keperilakuan berpengaruh secara parsial terhadap kepatuhan Wajib Pajak Restoran di Surabaya.

\section{METODE PENELITIAN}

\section{Jenis Penelitian}

Penelitian ini menggunakan pendekatan kuantitatif yaitu penelitian yang menitik beratkan pada pengujian hipotesis dengan alat analisa metode statistik dan menghasilkan kesimpulan yang dapat digeneralisasi. Asumsi-asumsi yang digunakan dalam penelitian ini adalah berupa variabel-variabel yang dapat diukur dan berguna untuk menjelaskan hubungan timbal balik (kausalitas) yang dimulai dengan hipotesis dan teori-teori.

\section{Populasi dan Sampel}

Populasi dalam penelitian mengenai analisis pengaruh sikap, norma subyektif, dan kontrol keperilakuan terhadap perilaku kepatuhan wajib pajak restoran di Surabaya adalah seluruh Wajib Pajak Restoran yang berada di kota Surabaya. Jumlah Wajib Pajak Restoran sebanyak 1612 pada tahun 2013.Data tersebut didapatkan dari Dinas Pengelolaan Keuangan Daerah Kota Surabaya.

Sampel dalam penelitian ini diambil menggunakan berdasarkan rumus Slovin dengan sampling eror 10\% (Umar, 2001):

$$
\begin{aligned}
& \mathrm{N}=\frac{\mathrm{N}}{1+N(\mathrm{e})^{2}} \\
& \mathrm{n}=\text { jumlah sampel } \\
& \mathrm{N}=\text { populasi } \\
& \mathrm{e}=\text { persen kelonggaran ketidaktelitian karena kesalahan pengambilan sampel } \\
& \quad \text { yang masih dapat ditolerir atau diinginkan, dalam penelitian ini } 0,1 .
\end{aligned}
$$

Berdasarkan dari DPPK Kota Surabaya hingga tahun 2012 tercatat 1612 Wajib Pajak Restoran. Oleh karena itu jumlah sampel untuk penelitian dengan margin of error sebesar $10 \%$ adalah:

$$
\begin{aligned}
N & =\frac{1612}{1+1612(0,1)^{2}} \\
& =\frac{1612}{1+16,12}=93,72=94 \text { Wajib Pajak Restoran }
\end{aligned}
$$


Berdasarkan sampel diatas, maka penelitian ini menggunakan sampel minimal 94 untuk Wajib Pajak Restoran.

\section{Metode Analisis}

Penelitian ini menggunakan alat analisis statistik untuk mengukur pengaruh beberapa variabel bebas terhadap variabel terikatnya. Berdasarkan variabel-variabel yang telah diuraikan dimuka, maka untuk menguji hipotesis digunakan model persamaan regresi linier berganda dengan persamaan sebagai berikut:

$$
\mathrm{Y}=\alpha+\mathrm{b}_{1} \mathrm{X}_{1}+\mathrm{b}_{2} \mathrm{X}_{2}+\mathrm{b}_{3} \mathrm{X}_{3}+\mathrm{e}
$$

Dimana :

$\mathrm{Y}=$ Kepatuhan Wajib Pajak

$\alpha=$ Konstanta

$\mathrm{X}_{1}=$ Sikap

$\mathrm{X}_{2}=$ Norma Subyektif

$\mathrm{X}_{3}=$ Kontrol Keperilakuan

$\mathrm{b}_{1} \ldots \mathrm{b}_{3}=$ Koefisien Regresi

$\mathrm{e}=$ Error

\section{Definisi Operasional}

\section{Variabel Kepatuhan Wajib Pajak (Y)}

Merupakan variabel terikat (Y) dimana kepatuhan Wajib Pajak yaitu suatu keadaan dimana Wajib Pajak memenuhi semua kewajiban perpajakan dan melaksanakan hak perpajakannya. Pengukuran Variabel kepatuhan Wajib Pajak diukur dengan mereplikasi Peraturan Daerah Nomor 4 Tahun 2011 Kota Surabaya mengenai kewajiban-kewajiban yang harus dipenuhi menjadi Wajib Pajak Patuh:

a. Kami melakukan pembayaran/pendaftaran bukan karena mendapat teguran dalam proses pelayanan

b. Sebagai Wajib Pajak, kami menganggap mendaftarkan diri sebagai suatu bagian penting dalam pemenuhan kewajiban pajak

c. Sebagai Wajib Pajak, kami berusaha menyampaikan laporan dengan tepat waktu

d. Sebagai wajib pajak, kami selalu berusaha agar data keuangan yang disampaikan sesuai dengan ketentuan yang berlaku

e. Kami tidak mau memanfaatkan kelemahan petugas untuk membayar pajak secara tidak benar

f. Kami selalu berusaha membayar di Bank/tempat yang telah ditentukan

g. Kami selalu berusaha membayar pajak sesuai dengan jumlah semestinya

h. Kami selalu berusaha menyajikan data-data pajak yang sebenarnya

i. Kami menyadari pentingnya kewajiban membayar pajak untuk kepentingan Negara. 


\section{Sikap $\left(\mathbf{X}_{1}\right)$}

Sikap menurut Ajzen (2005:2) merupakan sebuah disposisi atau kecenderungan untuk menggapai hal-hal yang bersifat evaluatif, disenangi atau tidak disenangi terhadap objek, institusi, orang, permaslahan tertentu atau peristiwa. Variabel sikap diukur dengan menggunakan indikator sebagai berikut :

a. Dilihat dari aspek ekonomi sikap mempertimbangkan keinginan membayar pajak lebih kecil dari yang seharusnya dengan keinginan untuk tidak melaporkan seluruh kegiatan usaha (Hidayat, 2010:87).

b. Dilihat dari aspek regulasi pemerintah, perasaan pemanfaatan pajak yang tidak transparan (Hidayat, 2010:87).

c. Dilihat dari aspek regulasi pemerintah, perasaan dirugikan oleh sistem perpajakan (Hidayat, 2010:87).

d. Sulitnya peraturan perpajakan, pengetahuan dan pemahaman peraturan perpajakan adalah proses dimana wajib pajak mengetahui tentang perpajakan dan mengaplikasikan pengetahuan itu untuk membayar pajak (Nugroho, 2012 dalam Sutari 2012).

\section{Norma Subyektif $\left(\mathbf{X}_{2}\right)$}

Merupakan faktor sosial menunjukkan tekanan sosial yang dirasakan untuk melakukan atau tidak melakukan tindakan/perilaku. Norma subyektif terbentuk dari keyakinan normatif dan motivasi dari pengaruh kelompok referen. Dalam hal ini individu dapat terpengaruh oleh pandangan orang lain dan dapat pula tidak terpengaruh. Sejauh mana individu akan terpengeruh atau tidak, sangat tergantung pada kekuatan kepribadian individu yang bersangkutan dalam menghadapi kehendak orang lain (Ajzen \& Fishbein, 1980). Indikator norma subyektif yang digunakan dalam penelitian ini adalah anggota keluarga, media cetak/elektronik, petugas pajak, dan menambahkan dari Arniati (2009) konsultan pajak. Variabel norma subyektif diukur dengan menggunakan indikator sebagai berikut:

a. Keluarga kandung (Ayah/Ibu/Adik/Anak) mendorong untuk melakukan kepatuhan Wajib Pajak

b. Pasangan mendorong untuk melakukan kepatuhan Wajib Pajak.

c. Keluarga bukan kandung (Paman/Bibi dan lain-lain) mendorong untuk melakukan kepatuhan Wajib Pajak

d. Kawan dekat (Kawan Sekolah/Kawan Sekerja) mendorong untuk melakukan kepatuhan Wajib Pajak

e. Media cetak/elektronik mendorong untuk melakukan kepatuhan Wajib Pajak.

f. Petugas Pajak mendorong untuk melakukan kepatuhan Wajib Pajak.

g. Konsultan Pajak mendorong untuk melakukan kepatuhan Wajib Pajak.

\section{Kontrol Keperilakuan $\left(\mathbf{X}_{3}\right)$}

Merupakan kondisi dimana orang percaya bahwa suatu tindakan itu mudah atau sulit dilakukan. Kontrol keprilakuan terbentuk dari keyakinan kontrol terhadap tindakan dan kemudahan yang dirasakan ke faktor kontrol. Sesuai dengan model 
pernyataan yang dikembangkan Francis, 2004 dalam hidayat widi 2010 responden diberi pernyataan mengenai tingkat keyakinan diri Wajib Pajak ingin melakukan ketidakpatuhan pajak namun bagi mereka melakukan ketidakpatuhan pajak merupakan hal yang sulit dilakukan karena ada beberapa faktor-faktor yang menghalangi. Penulis mereplikasi dari Peraturan Daerah No.4 Tahun 2011 Kota Surabaya mengenai pemeriksaan yang dilakukan fiskus, adanya sanksi denda administrasi, sanksi pidana dan menambahkan dari Erwin (2009:100) kemungkinan pelaporan pihak ketiga. Variabel kontrol keprilakuan diukur dengan menggunakan indikator sebagai berikut :

a. Kantor Pelayanan Pajak melakukan pemeriksaan pada Wajib Pajak untuk menguji pemenuhan kewajiban perpajakan dalam rangka pembinaan kepada Wajib Pajak

b. Adanya sanksi denda administrasi.

c. Adanya sanksi pidana.

d. Kemungkinan pelaporan pihak ketiga.

\section{Pengukuran Variabel}

Dalam penelitian ini pengukuran variabel menggunakan skala interval (Indriantoro dan Supomo, 1999:99) adalah skala pengukuran yang menyatakan kategori, peringkat dan jarak construct yang diukur dengan kata lain tidak hanya mengukur perbedaan subyek atau obyek secara kualitatif melalui kategorisasi dan menyatakan urutan preferensi, tetapi juga mengukur jarak antara pilihan yang satu dengan yang lain. Teknik pengukurannya menggunakan skala Likert.

Untuk pengukuran variabel penelitian ini responden diminta untuk menilai suatu obyek atau konsep dalam 5 (lima) point tingkatan yang menggunakan daftar pertanyaan atau kuesioner. Pengukuran dilakukan dengan skala Likert, skor jawaban berskala 1 sampai 5 dengan kriteria jawaban: STS (Sangat Tidak Setuju) skor 1, TS (Tidak Setuju) skor 2, KS (Kurang Setuju) skor 3, S (Setuju) skor 4 dan SS (Sangat Setuju) skor 5.

\section{HASIL DAN PEMBAHASAN}

Responden dalam penelitian ini adalah responden yang berjenis kelamin pria sebanyak 53 orang (56\%), kemudian yang berjenis kelamin wanita sebanyak 41 orang $(44 \%)$. Berdasarkan usia responden yang berusia 18-25 tahun sebanyak 9 orang $(9,6 \%)$, responden yang berusia $26-35$ tahun sebanyak 27 orang $(23,4 \%)$, responden yang berusia 36-45 tahun sebanyak 39 orang (41\%), dan responden yang berusia diatas 46 tahun sebanyak 19 orang (20\%). Menurut tingkat pendidikan 3 responden yang berpendidikan SMA sebanyak 20 orang $(21,27 \%)$, responden yang berpendidikan D3 sebanyak 19 orang $(20,21 \%)$, responden yang berpendidikan S1 sebanyak 34 orang $(36,17 \%)$, responden yang berpendidikan pasca sarjana sebanyak 13 orang $(13,82 \%)$, dan responden yang memiliki pendidikan lain-lain sebanyak 9 orang $(9,57 \%)$.

Responden dengan objek pajak restoran sebesar 7 objek pajak $(7,4 \%)$, objek pajak rumah makan sebanyak 6 objek pajak $(6,4 \%)$, objek pajak kafetaria sebanyak 4 
objek pajak $(4,4 \%)$, objek pajak kantin sebanyak 1 objek pajak $(1 \%)$, objek pajak depot sebanyak 16 objek pajak (17\%), objek pajak pujasera sebanyak 38 objek pajak $(40,4 \%)$, objek pajak toko roti sebanyak $2(2,1 \%)$, objek pajak Jasa Boga sebanyak 2 objek pajak $(2,1 \%)$.

\section{Analisis Regresi Linier Berganda}

Tabel 1. Analisis Regresi Linier Berganda

\begin{tabular}{cccc}
\hline No & Variabel & Koefisien Regresi & Std, Error \\
\hline 1. & Sikap (X1) & 0.254 & 0.030 \\
2. & Norma Subyektif (X2) & 0.371 & 0.045 \\
3. & Kontrol Keperilakuan (X3) & 0.259 & 0.050 \\
4. & Konstanta & 0.342 & 0.202 \\
\hline
\end{tabular}

Sumber: Output SPSS, diolah peneliti

Berdasarkan Tabel 1. diperoleh persamaan regresi linier berganda sebagai berikut:

$$
Y=0,342+0,254 X_{1}+0,371 X_{2}+0,259 X_{3}
$$

Persamaan regresi linier berganda tersebut menunjukkan nilai $\alpha$ (konstanta) sebesar 0,342 dan mempunyai nilai positif. Nilai tersebut berarti bahwa jika variabel bebas yaitu Sikap, Norma Subyektif, dan Kontrol Keperilakuan dengan 0 (nol) atau konstan, maka Kepatuhan Wajib Pajak adalah sebesar 0,342.

Nilai $\beta_{1}$ sebesar 0,254 tersebut mempunyai arti bila terjadi kenaikan sikap $\left(\mathrm{X}_{1}\right)$, variabel Norma Subyektif dan Kontrol Keperilakuan dianggap konstan, maka akan terjadi kenaikan Kepatuhan Wajib Pajak Sebesar 0,254.Nilai $\beta_{2}$ sebesar 0,371 tersebut mempunyai arti bila terjadi kenaikan Norma Subyektif $\left(\mathrm{X}_{2}\right)$, variabel Sikap dan Kontrol Keperilakuan dianggap konstan, maka akan terjadi kenaikan Kepatuhan Wajib Pajak sebesar 0,371.Nilai $\beta_{3}$ sebesar 0,259 tersebut mempunyai arti bila terjadi kenaikan Kontrol Keperilakuan $\left(\mathrm{X}_{3}\right)$, variabel Sikap dan Norma Subyektif dianggap konstan, maka akan terjadi kenaikan Kepatuhan Wajib Pajak sebesar 0,259.

Tabel 2. Nilai Koefesien Determinasi

Model Summary ${ }^{\mathrm{b}}$

\begin{tabular}{lrrrr}
\hline Model & R & R Square & Adjusted R Square & Std. Error of the Estimate \\
\hline 1 & $0.880^{\mathrm{a}}$ & 0.774 & 0.767 & 0.15124 \\
a. Predictors: (Constant), x3, x1, x & & & \\
b. Dependent Variable: $\mathrm{y}$ & & & \\
\hline
\end{tabular}

Sumber: Output SPSS, diolah peneliti

Variabel bebas yaitu sikap $\left(\mathrm{X}_{1}\right)$, norma subyektif $\left(\mathrm{X}_{2}\right)$ dan kontrol keperilakuan $\left(\mathrm{X}_{3}\right)$ mampu menjelaskan perubahan variabel Kepatuhan Wajib Pajak sebesar 77\% (lihat R 
Square 0,774$)$ sedang sisanya $22,6 \%(100 \%$ - 77,4\%) dijelaskan oleh variabel lain selain sikap, norma subyektif, dan kontrol keperilakuan.

Tabel 3. Hipotesis Pengaruh Secara Bersama-sama

\begin{tabular}{llrrrrr}
\hline & \multicolumn{5}{c}{ ANOVAb } & \multicolumn{1}{c}{ Sig. } \\
\hline 1 & & Sum of Squares & df & Mean Square & \multicolumn{1}{c}{ F } & \multicolumn{1}{c}{ Sig } \\
& Regression & 7.064 & 3 & 2.355 & 102.946 & $.000^{\mathrm{a}}$ \\
& Residual & 2.058 & 90 & .023 & & \\
& Total & 9.122 & 93 & &
\end{tabular}

a. Predictors: (Constant), kontrol Keperilakuan, sikap, norma Subyektif

b. Dependent Variable: kepatuhan wajib pajak

Sumber: Output SPSS, diolah peneliti

Berdasarkan tabel 3 nilai F sebesar 102,946 dengan Sig 0,000 < 0,05: Signifikan positif, berarti secara bersama-sama perubahan ketiga variabel bebas yaitu sikap $\left(\mathrm{X}_{1}\right)$, norma subyektif $\left(\mathrm{X}_{2}\right)$ dan kontrol keperilakuan $\left(\mathrm{X}_{3}\right)$ mampu menjelaskan perubahan variabel Kepatuhan Wajib Pajak.

Tabel 4. Hasil Uji Hipotesis Secara Parsial

\begin{tabular}{lcc}
\hline \multicolumn{1}{c}{ Variabel } & t hitung & Signifikan \\
\hline Sikap (X1) & 8.350 & .000 \\
Norma Subyektif (X2) & 8.319 & .000 \\
Kontrol keperilakuan (X3) & 5.220 & .000 \\
\hline Swber
\end{tabular}

Sumber: Output SPSS (Diolah penulis)

Berdasarkan hasil perhitungan disimpulkan bahwa secara bersama-sama variabel bebas yaitu Sikap (X1), Norma Subyektif (X2) dan Kontrol Keperilakuan berpengaruh signifikan positif terhadap variabel terikat Kepatuhan Wajib Pajak. Hal ini dikarenakan bahwa ketiga komponen ini berinteraksi dan menjadi determinan bagi intensi/niat yang pada gilirannya akan menentukan apakah perilaku yang bersangkutan akan dilakukan atau tidak. Sikap terhadap suatu perilaku dipengaruhi oleh kecenderungan untuk menanggapi hal-hal yang bersifat evaluatif, disenangi atau tidak disenangi terhadap objek, orang, instansi atau peristiwa. Keyakinan yang bersifat normatif (yang diharapkan oleh orang lain) motivasi untuk bertindak sesuai dengan harapan normatif tersebut membentuk norma subyektif dalam diri individu. Kontrol keperilakuan yang dirasakan ditentukan oleh keyakinan individu akan ada atau tidaknya faktor yang mendukung atau menghalangi akan munculnya tingkah laku dan keyakinan pengalaman masa lalu. Kontrol keperilakuan menjadi sangat penting ketika rasa percaya diri seseorang sedang berada pada konsisi yang sangat lemah.

Hasil penelitian ini sesuai dengan temuan Mustikasari Elia (2007:3) yang menyatakan bahwa perilaku kepatuhan wajib pajak sangat dipengaruhi oleh variable sikap, norma subyektif, dan control keperilakuan yang dipersepsikan, selain itu dalam 
perhitungan didapat bahwa ada pengaruh Sikap (X1) terhadap Kepatuhan Wajib Pajak. Hal ini dikarenakan sikap dimulai dari adannya perasaan dan penilaian seseorang untuk mendukung atau memihak yang ditentukan secara langsung oleh keyakinan terhadap perilaku kepatuhan Wajib Pajak.

Hasil penelitian ini mendukung temuan dari Kahono, (2003) yang menyatakan bahwa sikap dapat mempengaruhi kepatuhaan Wajib Pajak. Hasil perhitungan dalam penelitian ini juga didapat ada pengaruh Norma Subyektif (X2) terhadap Kepatuhan Wajib Pajak. Hal ini dikarenakan norma subyektif merupakan persepsi seseorang akan tekanan sosial (motivasi dari pengaruh referen) untuk menunjukkan atau tidak menunjukkan tingkah laku pertimbangan tertentu. Dalam hal ini individu dapat terpengaruh oleh pandangan orang lain dan dapat pula tidak terpengaruh. Sejauh mana individu akan terpengaruh atau tidak, sangat tergantung pada kekuatan kepribadian individu yang bersangkutan dalam menghadapi kehendak orang lain. (Ajzen \& Fishbein, 1980). Temuan ini mendukung hasil penelitian dari Hidayat (2010:91) yang menyatakan bahwa norma subyektif berpengaruh terhadap kepatuhan wajib pajak. Semakin besar tekanan sosial/norma subyektif dari lingkungan responden untuk tidak patuh pajak, semakin besar pula niat seseorang untuk tidak patuh, demikian pula sebaliknya.

Hasil perhitungan dalam penelitian ini juga didapat ada pengaruh Kontrol Keperilakuan (X3) terhadap Kepatuhan Wajib Pajak. Hal ini dikarenakan bahwa kontrol keperilakuan terbentuk dari keyakinan individu aka ada atau tidaknya faktor yang mendukung atau menghalangi akan munculnya tingkah laku. Ajzen telah menyatakan bahwa kontrol keperilakuan yang dirasakan dapat berpengaruh pada niat dan dapat berpengaruh baik secara langsung maupun secara tidak langsung pada perilaku itu sendiri. (Ajzen \& Fishbein, 1980). Hasil penelitian ini

mendukung pendapat dari Hidayat (2010:91) yang menyatakan bahwa semakin besar persepsi seseorang akan tingkat kontrol terhadap perilaku, semakin kecil kemungkinan perilaku ketidakpatuhan yang akan ditampilkan, hal ini berarti bahwa jika kontrol seseorang memiliki nilai yang tinggi wajib pajak cenderung untuk berperilaku patuh.

Hasil penelitian ini menunjukkan bahwa dalam theory of planned behavior, yang diukur yaitu variabel sikap, norma subyektif, dan kontrol keperilakuan yang dirasakan, berinteraksi dan menjadi determinan bagi intensi/niat yang pada gilirannya akan menentukan apakah perilaku yang bersangkutan akan dilakukan atau tidak. Peneliti mengharapkan hasil penelitian ini dapat lebih meningkatkan lagi kepatuhan Wajib Pajak, karena pajak berfungsi untuk memasukkan dana secara optimal ke kas Negara berdasarkan Undang-Undang perpajakan yang berlaku dan mengawasi kegiatan ekonomi masyarakat.

\section{SIMPULAN}

Berdasarkan data kuisioner yang telah dikumpulkan terhadap 94 Wajib Pajak Restoran di Surabaya dan pengujian yang dilakukan terhadap permasalahan dengan menggunakan model analisis regresi, maka dapat diambil kesimpulan sebagai berikut: 
1. Sikap, Norma Subyektif dan Kontrol Keperilakuan berpengaruh secara simultan atau bersama-sama terhadap Perilaku Kepatuhan Wajib Pajak Restoran di Surabaya. Hal ini berarti secara bersama-sama Sikap, Norma Subyektif dan Kontrol keperilakuan berpengaruh terhadap kepatuhan wajib pajak restoran, saling mendukung bersama-sama meningkatkan perilaku patuh Wajib Pajak Restoran di Surabaya.

2. Sikap, Norma Subyektif dan Kontrol Keperilakuan berpengaruh secara parsial terhadap Perilaku Kepatuhan Wajib Pajak Restoran di Surabaya. Hal ini berarti masing-masing variabel bebas (Sikap, Norma Subyektif dan Kontrol Keperilakuan) berpengaruh secara positif terhadap Perilaku Kepatuhan Wajib Pajak Restoran di Surabaya. Semakin positif Sikap, Norma Subyektif, dan Kontrol Keperilakuan seorang Wajib Pajak Restoran (dalam hal ini mendukung) terhadap kepatuhan pajak maka semakin tinggi tingkat kepatuhan Wajib Pajak Restoran. Sebaliknya, semakin negatif Sikap, Norma Subyektif dan Kontrol Keperilakuan seorang Wajib Pajak Restoran (dalam hal ini berarti tidak mendukung) terhadap kepatuhan pajak maka semakin rendah tingkat kepatuhan pajak Wajib Pajak Restoran di Surabaya. 


\section{DAFTAR PUSTAKA}

Admino. 2009. Analisis faktor-faktor yang mempengaruhi tingkat kepatuhan masyarakat terhadap ketentuan umum perpajakan khususnya pajak penghasilan. Skripsi Perpajakan.

Ajzen,Icek. 2005. Attitudes, Personality and Behavior 2nd ed. New York; Open University Press.

Ajzen and Fishbein's. 1992. Personality and Individual Differences. Journal of Experimental Social Psychology. Vol. 62.No. 1.

Ajzen, Icek,\& Manstead, A. S. R. 2007. Changing Health-Related Behaviors: An Approach Based On The Theory Of Planned Behavior. In K. Van Den Bos, M. Hewstone, J. De Wit, H. Schut \& M. Stroebe (Eds.).The scope of Social psychology: Theory and applications (pp. 43-63). New York: Psychology Press.

Departemen Dalam Negeri RI. Undang-Undang Nomor 28 Tahun 2009 Tentang Pajak Daerah dan Retribusi Daerah.

Departemen Dalam Negeri RI. Peraturan Daerah Nomor 2 Tahun 2003 Tentang Pajak Restoran.

Departemen Dalam Negeri RI. Peraturan Daerah Nomor 4 Tahun 2011 Tentang Pajak Daerah.

Ghozali, Imam. 2006. Aplikasi Analisis Multivariate dengan program SPSS. Semarang: Badan Penerbit Universitas Diponegoro.

Hakim, Abdul. 2011. "Tunggakan Pajak Daerah Surabaya Capai 31,7 Miliar" (online), Antara News web, (http://jatim.antaranews.com/ antarajatim1/lihat/berita/66747/tunggakan-pajak-daerah-surabaya-capairp317-miliar, diakses 3 juni 2013).

Haryono, Aan. 2012. "Tunggakan Pajak Resto tembus 4 Miliar" (Online), Harian Seputar Indonesia web,(http://www.ortax.org/ortax/?mod=berita\& page $=$ show $\&$ id $=12330 \& q=\& h l m=54$, diakses 3 Juni 2013).

Hidayat, widi dan Arga Adi. 2010. Study Empiris TPB dan Kewajiban Moral terhadap Perilaku Tidak Patuh Wajib Pajak Pribadi. Jurnal Akuntansi, (online), Vol. 12, No.2.

Kahono, Sulud. 2003. Pengaruh Sikap Pajak Terhadap Kepatuhan Wajib Pajak Dalam Pembayaran Pajak Bumi dan Bangunan (Studi Empiris di Wilayah KP.PBB Semarang). Semarang: Universitas Diponegoro.

Mustikasari, Elia. 2007. Kajian Empiris Tentang Kepatuhan Wajib Pajak Badan Di Perusahaan Industri Pengolahan Di Surabaya. Simposium Nasional Akuntansi $X$. Unhas Makasssar 26-28 Juli.

Suandy, Erly. 2001. Hukum Pajak. Jakarta: Salemba Empat.

Sugiyono. 2004. Metode Penelitian Bisnis. Bandung: CV. Alfabeta.

Sutari, dewi. 2013. Faktor-faktor yang mempengaruhi kemauan membayar pajak sebagai perwujudan masyarakat madani. Seminar nasional 2013.Fakultas ekonomiuniversitas sarjanawiyatataman siswa. 
Tarjo.2009. Analisis Faktor-faktor yang Mempengaruhi Perilaku Kepatuhan Wajib Pajak Orang Pribadi di Bangkalan. Simposium Nasional Perpajakan 2, Trunojoyo.

Trivedi, Shehata dan Mestelman. 2005. "Attitudes, Incentives, and Tax Compliance". Working paper 1-29 (Department of Economics McMaster University). .2002.Constructing a TPB Questionnaire: Conceptual and Methodological Considerations. September (Revised January, 2006). .1998.The Theory of Planned Behavior.Organizational Behaviour and Human Decision Processes 50 (2). 